\title{
Effect on harvesting at different stages of growth and long-term storage on phenolics in sorghum stover
}

\author{
K. Khazaal' ${ }^{1}$ I. Mueller-Harvey' ${ }^{1}$, A. B. McAllan ${ }^{1}$, E. Osafo ${ }^{2}$, E. Owen ${ }^{2}$ and A. N. Said ${ }^{3}$ \\ ${ }^{1}$ AFRC Institute of Grassland and Environmental Research, Hurley Research Station, Hurley SL6 5LR \\ ${ }^{2}$ Department of Agriculture, University of Reading, Reading RG6 2AT \\ ${ }^{3}$ International Livestock Centre for Africa, PO Box 5689, Addis Ababa, Ethiopia
}

\section{Introduction}

Sorghum (Sorghum bicolor) is an important food crop in Africa for human (grain) and animal (crop residues) consumption. However, digestion of crop residues by rumen micro-organisms is often limited by the presence of polyphenolic compounds (Reed, Kebede and Fussell, 1988; Butler, 1989; Ford and Hartley, 1990). In Ethiopia, leaf stripping of sorghum for animal feeding during plant growth is common practice as is storing the stover for some months after harvesting, before feeding. Therefore it is essential to know if either practice has any effect on the phenolic content and composition of the plant and hence on nutritional quality.

The aim of the present experiment was to study changes in the concentrations and composition of phenolic compounds in component parts of different sorghum varieties harvested at different growth stages and also after long-time storage.

\section{Material and methods}

Sorghum varieties, growing conditions and harvesting

Seredo, X/35:24 or Ikinyaruka (bird resistant) and Dinkamash (non-bird resistant) varieties were grown in triplicated plots in Ethiopia (Melkasa; elevation $1500 \mathrm{~m})$. Sampling was at $50 \%$ flowering $(50 \%$ of the plants have flowered), black layer (most grains have black spot) and harvest (plants are mature and ready for harvest).

\section{Treatment and extraction of sorghum samples}

Harvested leaves were fractionated into leaf blade (LB) or leaf sheath (LS), air-dried and ground (1 mm). $50 \mathrm{mg}$ samples were extracted in $2 \mathrm{ml}$ acetone/water $(7: 3, v / v)$.

High pressure liquid chromatography (HPLC) analysis Extracts $(20 \mu \mathrm{l})$ were injected into HPLC $\left(\mu\right.$-Bondapack $\mathrm{C}_{18}$ column, at $\left.30 \pm 1^{\circ} \mathrm{C}\right)$; water/acetic acid $(975: 25, \mathrm{v} / \mathrm{v})$ and methanol were used as solvents at $1.3 \mathrm{ml} / \mathrm{min}$. A 990 photodiode array detector was used to record spectra between 230 and $600 \mathrm{~nm}$.

\section{Results}

There were large differences in the shape of chromatograms indicating differences in phenolic components both in composition and concentration between LB and LS of each of the varieties used. The difference between varieties appeared to be larger in LS than in LB (Figure 1). Additionally, in LS, differences between replicates were noticed at the $50 \%$ flowering and black layer stages, whereas in LB the differences were apparent at $50 \%$ flowering stage only. These findings indicate that the biosynthesis of phenolics is completed (stabilized) in LB before LS.

From the chromatograms of $X / 35: 24$ or Seredo varieties (Figure 1) it can be seen that large differences in phenolics exist between the $50 \%$ flowering stage in comparison with the other two stages especially in LS fraction.

Storage of the samples at room temperature $\left(15^{\circ} \mathrm{C}\right)$ for 3 months after harvest did not appear to influence either the phenolic content or its composition of either LS or LB.

\section{Conclusion}

Beside varietal and fractional effects, phenolic compounds are influenced by growth stages up to black layer stage. However storage did not appear to affect phenolic compound content or composition.

\section{Acknowledgements}

The financial support of Overseas Development Administration is gratefully acknowledged. 

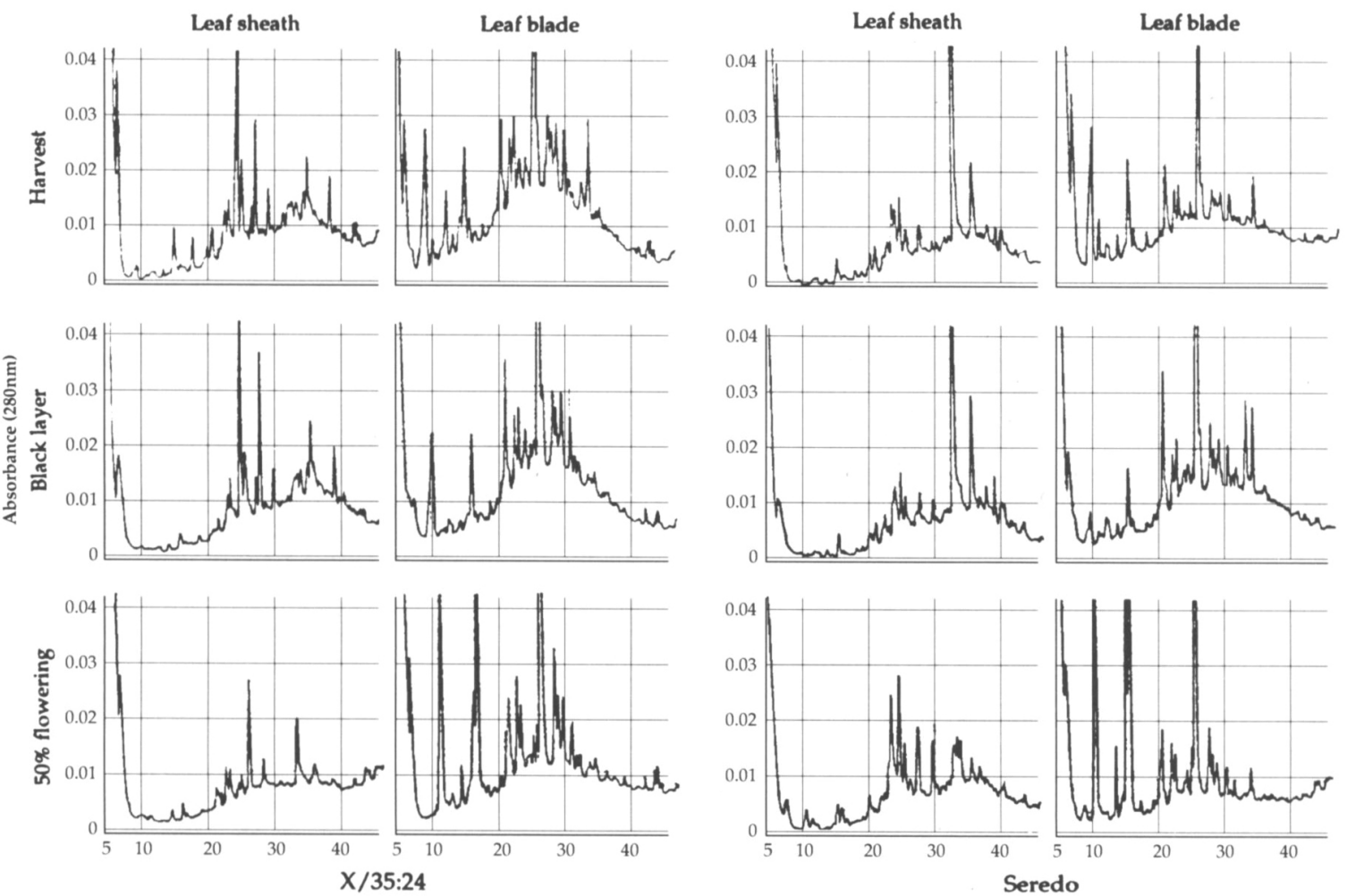

Figure 1 HPLC of aqueous acetone extracts from leaf blade or leaf sheath fractions of the Ethiopian sorghum varieties $\mathrm{X} / 35: 24$ or Seredo at different growth stages.

\section{References}

Butler, L. G. 1989. Sorghum polyphenols. In Toxicants of plant origin. IV. Phenolics (ed. P. R. Cheeke), pp. 95-121. CRC Press.

Ford, C. W. and Hartley, R. D. 1990. Cyclodimers of p-coumaric and ferulic acids in the cell walls of tropical grasses. Journal of the Science of Food and Agriculture 50: 29-43.

Reed, J. D., Kebede, Y. and Fussell, L. K. 1988. Factors affecting the nutritive value of sorghum and millet crop residues. In Plant breeding and the nutritive value of crop residues (ed. J. D. Reed, B. S. Capper and P. J. H. Neate), International Livestock Centre for Africa, Addis Ababa. 